\title{
Comparing the impact of leader-member exchange, psychological empowerment and affective commitment upon Australian public and private sector nurses: Implications for retention
}

\begin{abstract}
This study uses Leader-Member Exchange (LMX) theory to test the associations between the supervisor-subordinate relationship, psychological empowerment and affective commitment amongst 1283 nurses working in Australian public and private hospitals. Both qualitative and quantitative data were collected, analysed and are presented. The findings show that the quality of leader-member exchange is more important in public sector nursing contexts than in the private sector with regard to the relationship between empowerment and affective commitment. Further, the relationship between empowerment and affective commitment is stronger for nurses in public sector organisations with low quality leader-member exchange than for nurses in public sector organisations with high quality leader-member exchange. As empowerment and affective commitment are both predictors of staff retention, the findings can assist in developing targeted current and future retention strategies for healthcare management.
\end{abstract}




\section{Comparing the impact of leader-member exchange, psychological empowerment and affective commitment upon Australian public and private sector nurses: Implications for retention}

\section{Introduction}

Australia faces a three percent shortage of practicing registered nurses (AIHW, 2004), equivalent to 10,000 nurses, just to meet present demand (Chang, 2000). Approximately one-quarter of Australian nurses currently work in other occupations (ABS, 2005). Moreover, Australian female workers tend to retire early at an average age of 47 years (ABS, 2009). The situation is likely to become increasingly critical because two thirds of Australian nurses are currently aged between 45 and 65 years and there is a trend towards older nurses retiring early (Sutton, Bell and Narz, 2007). This nursing shortage negatively impacts on the health of Australians because it affects both patient and nurse outcomes (Rafferty, Clarke, Coles, Ball and James, 2007). Research suggests that the main factors affecting the supply of nurses include an aging population, inadequate numbers attracted to the profession and high turnover (Buchan and Calman, 2004; Buerhaus, Staiger and Auerbach, 2007; Schofield and Beard, 2005). Notably, management scholars have identified an effective supervisor-subordinate relationship as the factor most likely to improve nurse commitment and retention (Cohen, 2006; Taunton, Boyle and Woods, 1997). Consequently, new knowledge about the impact of supervisor-nurse relationships upon nurses' commitment is important for healthcare management.

A useful lens for examining the impact of supervisor-subordinate relationships is the leadermember exchange theory (LMX). This theory argues that supervisors manage their employees differently, leading to different outcomes from different groups of employees. Over time, the quality of these "social exchanges" leads to a diverse quality of relationships between supervisors 
and subordinates. Effective (high quality) LMX relationships are characterised by high levels of mutual support, trust and respect (Gerstner and Day 1997; Mueller and Lee 2002). LMX captures the impact of employee perceptions of support from their supervisors, and this may prove valuable for examining the impact of the supervisor-nurse relationship upon psychological empowerment and affective commitment, which are often associated with intention to leave. In this study, we focus on the relationships between nurse unit managers and their subordinates.

The healthcare sector has undergone significant downsizing and re-engineering, including eliminating nursing positions, and consequently changing the nature and substance of nursing and nurse management (Bolton, 2001; 2002; 2004; Buchanan and Considine, 2002; Upenieks, 2003). While there are studies examining the impact of these changes upon nurses generally, there is a dearth of literature comparing nurses' experiences in public and private hospital settings. This is important because the public sector has undergone 30 years of reform in management practices in OECD countries such as United Kingdom, Australia and New Zealand (Bolton, 2003; Pollitt, 1995). In particular, public sector nurses have been affected by changes in supervision practices resulting from an increase in managerial prerogative and organisational controls aimed at restricting nurses’ empowerment at the workplace (Kirkpatrick, Ackroyd and Walker, 2004). There is also a perception that private sector hospitals are better at attracting and retaining nurses than public hospitals (Mrayyan, 2005). It is therefore expected that public sector nurses will experience lower perceptions of psychological empowerment compared with private sector nurses. However, no studies have been undertaken to confirm this, nor has research examined the consequences of findings on affective commitment. Therefore, in this paper we examine the relationship between LMX, psychological empowerment and affective commitment, as well as compare these relationships across ten private and public sector hospitals. 
This paper has four parts. The first part provides a targeted review of the literature from which the hypotheses emerge. The second part describes the sample and methods to test the hypotheses. The third part reports the results, while the fourth part includes the discussion section to identify pattern-matching with relevant past research, plus the implications for hospital managers, followed by the conclusion.

\section{Leader-Member Exchange (LMX) Theory}

LMX theory argues that high quality supervisor-subordinate relationships are characterised by high levels of mutual support, trust and respect, including access to information and participation in decision-making. Such high quality supervisor-subordinate relationships result in employees who can undertake and complete tasks quicker and can solve work-related problems more efficiently and effectively compared with employees in low quality relationships (Gerstner and Day, 1997; Mueller and Lee, 2002). It is likely that employees in high quality supervisor-subordinate relationships will also have access to relevant information and resources, as well as, an empowering relationship, because supervisors allocate increased levels of organisational resources (time) towards them (Sparrowe and Linden, 1997). Basu and Green (1995) argue that the supervisors and their organisations may benefit because employees who are dedicated often demonstrate creativity and enterprise in the workplace and have increased esteem and loyalty to their supervisor and organisation. High quality supervisor-subordinate relationships are likely to encourage supervisors to delegate decision-making and power to their subordinates. In contrast, low quality relationships result in employees who tend to have poor levels of information-sharing and involvement in decision-making and in turn, lower levels of perceived empowerment (Wayne, Shore and Linden 1997; Yrie, Hartman, and Galle, 2003).

LMX theory suggests that the ideal situation is that all employees experience high quality 'social exchanges'. Workplace relationships are especially vital for women (Shacklock, Brunetto and 
Nelson, 2009) and importantly, the significance of relationships increases with age for nurses (Moseley, Jeffers and Patterson 2008). Some scholars have identified the supervisor-subordinate relationship as the factor most likely to improve commitment to the organisation (Brunetto, FarrWharton and Shacklock, 2010) and retention (Cohen, 2006; Taunton, et al, 1997). Hence, using the LMX theoretical framework, it is expected that the quality of supervisor-nurse relationships would affect nurses’ perceptions of psychological empowerment. The following hypothesis examines this proposition:

H1: Public and private sector nurses' satisfaction with their supervisor-subordinate relationships is positively associated to their perceptions of psychological empowerment

\section{Empowerment}

Empowerment can be defined as "a process of enhancing feelings of self-efficacy among organisational members” (Conger and Kanungo, 1988, 474) and moving away from 'control' to commitment-oriented strategies (Walton, 1985). Empirical research has demonstrated that psychological empowerment is particularly important in work environments that have experienced considerable amount of shortages and low morale, such as in the health sector (Harmon, Scotti, Behson, Farias, et al. 2003; Scotti, Harmon, and Behson, 2007). There is some evidence to suggest that employees who experience psychological empowerment feel committed to their job, resulting in higher levels of performance (Harmon et al. 2003; Laschinger, Finegan, Shamian, and Wilk, 2004). Psychological empowerment has been linked to greater job satisfaction (Spreitzer, Kizilos and Nason, 1997) organisational commitment (Spreitzer, 1995) and employee productivity (Larrabee, Withrow, Janney, Hobbs, Ostrow and Burant, 2003; Morrison, Jones, and Fuller, 1997). Psychological empowerment can be viewed as a tool to encourage workers to think for themselves about the requirements of their job, develop meaning in the tasks they are assigned to do and to enhance their competency levels in all area of their work (Laschinger et al. 2004). Psychological empowerment focuses on the psychological state of employees and is compartmentalised into four 
cognitions: meaning; competence; self-determinatio; and impact (Spreitzer, 1995). 'Meaning’ refers to the importance that is placed on the individual's job. 'Competence' can be thought of as selfefficacy - the extent to which an individual believes that they possess the capacity to undertake the work. 'Self-determination' or autonomy refers to the ability to self-direct one's work. 'Impact' refers to the extent to which an individual perceives that they have an impact on their immediate work environment such as on customers, clients and the organisational performance (Avolio, Zhu, Koh and Bhatia, 2004).

Linden, Wayne and Sparrowe $(2000,410)$ argue that "empowerment may contribute to a sense of commitment to the organization through a process of reciprocation”. Reciprocity occurs when one person treats another well, and the reciprocity norm may oblige employees to recompense advantageous treatment they receive from their organization (Rousseau, 1989; Eisenberger, Armeli, Rexwinkel, Lynch and Rhoades, 2001). Intuitively, organizations that provide jobs that encourage empowerment by ensuring that employees build competence, encouraging employees to positively impact their immediate work environments and creating roles for employees that are meaningful, should encourage greater identification with the goals of management, loyalty and attachment to the organization (Linden, et al., 2000). Moreover, Laschinger, Finegan and Shamian (2001) investigate the impact of workplace empowerment and organizational trust on nurses' work satisfaction and organizational commitment. The authors argue that empowering workers includes providing access to information and the necessary resources to do the job, support, and an opportunity to learn and grow. As predicted, they find that psychological empowerment has a direct effect on affective commitment.

Within Australia, research has found that few workplaces actively promote and encourage employee empowerment (Gollan 2005), and in the healthcare sector specifically, there has been 
little emphasis on effective empowerment strategies (Lloyd, Braithwaite, and Southon 1999). Therefore, we test the following hypothesis:

H2: Public and private sector nurses' perceptions of psychological empowerment are positively associated to their levels of affective commitment.

\section{Affective Commitment}

Affective commitment can be defined as the emotional attachment to, and identification with, an organisation (Allen and Meyer, 1990). Previous research has identified that employees with high levels of affective commitment are likely to be loyal and attached to the organisation, thereby reducing their likelihood of leaving the organisation (Meyer and Allen, 1997; Pitt, Leyland, Foreman and Bromfield, 1995). Affective commitment is significantly effected by the quality of supervisor-subordinate relationships (Gerstner and Day, 1997).

Meyer and Allen (1997) note that a central theme in commitment research involves the extent to which employees are made to feel that they make valuable contributions to their organization. According to Meyer and Allen (1997, 48), 'for some employees, the importance of their contributions is communicated through the trust the organization appears to place in their workrelated judgements'. Consistent with this point, affective commitment has been positively related to participation in decision making (Rhodes and Steers, 1981), latitude or discretion over activities (DeCotiis and Summers, 1987; Gregersen and Black, 1992), task autonomy (Dunham, Grube and Castaneda, 1994), receptiveness of management to employee ideas (Allen and Meyer, 1990), and job scope (Mathieu and Zajac, 1990; Meyer, Allen and Gellatly, 1990).

Previous research has demonstrates that there is an association between organisational commitment and employee empowerment. Herman and Gioia (1998) argue that for work to be 
meaningful (one of the four dimensions of psychological empowerment) the work needs to be a valued part of the organization, employees need to know not only how the work they do affects others and the organization's strategic goals, but also how employees can make an impact. Responsibility for outcomes, measurement of results and meaningful rewards are also important components of increasing the meaningfulness of work. Mottaz (1988) found that task significance is positively associated with organizational commitment. There is limited research concerning the relationship between meaningfulness and impact with organizational commitment (Mathieu and Zajac, 1990).

Mathieu and Zajac’s (1990) meta-analysis revealed that perceived competence, another of the four dimensions of psychological empowerment, exhibited a large positive correlation with commitment across five samples. Morris and Sherman (1981) interpreted this finding as indicating that self-referent processes may serve as a means of linking an individual to an organization. That is, individuals will become committed to an organization, so long as it satisfies their growth and achievement needs. This interpretation is tentative due to the limited research in the area. Morris and Sherman (1981) also reported that perceived competence emerged as a significant predictor of organizational commitment.

In the most comprehensive study linking Spreitzer's (1995) conceptualization of empowerment and affective commitment, Linden, et al. (2000) found that two of the four cognitions of empowerment (namely, meaning and impact) were significant predictors of affective commitment. At a team level of analysis, Kirkman and Rosen (1999) found a direct relationship between empowerment and affective commitment. Based on a review of the literature, the following hypothesis is proposed:

H3: Public and private sector nurses' affective commitment is positively associated with their perceptions of psychological empowerment and supervisor-nurse relationships. 


\section{Public and private hospitals in Australia}

While Australia provides universal access to health care, national government policy directions have resulted in a strong role for private health insurance and consequently, for private hospitals in meeting the health care needs of the population. Public hospitals provide around $61 \%$ of all hospitals admissions and receive their funding from public sources such as Medicare and taxation (Australian Institute of Health and Welfare, 2008). Public hospitals are required to provide access to care for all Australians.

In addition to public hospitals, private hospitals in Australia (which provide the other 39\% of all hospital admissions) can be divided into two main groups: private for-profit hospitals and private not-for-profit hospitals. Private for-profit hospitals in Australia tend to be owned or managed by private companies and operate to generate profit for shareholders. In contrast, private not-for-profit hospitals are often owned and sponsored by denominational organisations such as the Catholic church. Private hospitals may receive some public funds in specific service or management agreements, but are largely reliant on private health insurance, direct patient payments and other non-government payments, such as workers’ compensation. This combined funding contributes about 31\% to the entire Australian health budget (Australian Institute of Health and Welfare, 2008). There is continuing long-term growth in private hospital utilisation (Australian Institute of Health and Welfare, 2008) and the government is therefore heavily reliant on a strong private health care sector.

Although there have been few Australian studies, in other countries it has been shown that the for-profit and not-for-profit health sectors make different spending decisions. For example, in Canadian studies, public government-operated facilities were found to provide more hours of direct 
patient care than for-profit facilities (Berta, LaPorte, and Valdemanis 2005; McGregor, Cohen, McGrail, and et al. 2005). Some authors have suggested that given similar levels of funding, forprofit private hospitals must, by definition, divert some of their funding to profits and since staffing costs account for a large portion of total budget expenditures, this is a natural place to try to realize cost savings (McGrail, McGregor, Cohen, Tate, and Ronald, 2007). In Australia, studies have shown that health practitioners and the general public expect private hospitals to deliver higher quality of care than public hospitals (Hardie and Critchley, 2008) and there are studies demonstrating this higher level of private hospital patient care (see Robertson and Richardson, 2000). Yet, it is also largely acknowledged that public sector facilities care for patients with greater health needs, and analysis that takes these levels of complexity into account suggests that 'hospital care in the public sector is provided at higher levels of technical, allocative and dynamic efficiency than in the private sector' (Duckett and Jackson, 2000, 440).

Based on the different resource allocation decisions and pressures facing the sectors, it is often suggested that private hospitals will have different management practices from public sector hospitals. The literature suggests three reasons why these differences may occur. First, public hospitals need to respond to a more complex range of stakeholders than private companies accountable solely to shareholders. Specifically, pubic hospitals try to balance the conflicting goals of quality, equity and accountability in care delivery while still trying to maintain their essential teaching and research mission. Second, public hospitals are open systems that are influenced by external events that may not have the same impact on private organisations, and because public hospitals are publicly accountable. Third, the nature of public policy-making means there may be frequent changes in policy that will impact upon the operations of a public hospital to a greater extent than a private hospital (Baldwin 1990; Coursey and Bozeman 1990), particularly with respect to meeting the need for hospital beds or decisions about what are acceptable waiting lists, and changes in management reforms implemented by government. 
It has been shown that as a result of these constraints, public sector managers will have lower levels of autonomy (a key component of psychological empowerment) than managers in comparable private organisations (Baldwin, 1990). In a systematic review of the literature, Boyne (2002) found support for the assertion that public organisations are more bureaucratic than private organisations. Boyne (2002) also argues that research has consistently shown that public sector managers demonstrate a stronger desire to serve the public interest than comparable private sector managers.

The Australian public healthcare sector has undergone many years of reforms. Arguably greater bureaucratic management policies and practices have been enacted in public hospitals relative to private sector hospitals. Consequently, we argue that this may have a negative impact on nurse-supervisor relationships in public hospitals relative to private hospitals. Using the LMX framework, public sector nurses as compared with private sector nurses would be expected to experience lower levels of satisfaction with their supervisor-subordinate relationships. Therefore, public sector nurses may also perceive lower levels of empowerment and affective commitment. In contrast, it is expected that private sector nurses, compared with public sector nurses, will experience higher levels of satisfaction with the supervisor-subordinate relationship, and in turn, experience higher perceptions of empowerment and affective commitment.

H4: Private sector nurses experience higher levels of satisfaction with their supervisor-nurse relationships, and higher perceptions of psychological empowerment and affective commitment, compared with public sector nurses.

\section{METHODS}


This research uses both quantitative and qualitative methods to gather data to test the hypotheses. All the data were obtained from 7 private and 3 public hospitals across four states of Australia between 2007 and 2008 (see Table 1).

[Insert Table 1 here]

\section{Quantitative Data}

A cross-sectional research design was used to gather quantitative data to compare whether the quality of relationships between public and private sector nurses and their supervisors affects nurses’ perceptions of psychological empowerment and affective commitment. Data were collected using a survey-based, self-report strategy (Ghauri and Gronhaug, 2002). The emerging patterns of data were then compared with the findings of previous research.

\section{Measures}

The measures were generated from the extant literature and each measure was presented using statements rated on a 5-point Likert-type scale, with 1 = strongly disagree, up to 5 = strongly agree. The measures are explained below.

Satisfaction of nurses with the quality of their supervisor-subordinate relationship was measured using an adapted seven-item uni-dimensional scale (LMX-7), developed by Graen and Uhl-Bien (1995). One item is, 'I have a good working relationship with my supervisor'. The Reliability analysis demonstrated a high level of internal consistency for the LMX measure with a Cronbach's alpha of 0.80 .

Psychological Empowerment was operationalised using an adapted version of Spreitzer's (1995) 12-item measure of self-determination, impact, competence and meaning, including, 'I have opportunities for independence and freedom in how I do my job'. We conducted principal component analysis. All of the four dimensions loaded onto their respective dimensions. Cronbach’s alpha for the summated measure of psychological empowerment was 0.85. 
Affective commitment (the dependent variable), measuring an employee's commitment to their hospital, was operationalised using an adapted version of Allen and Meyer's (1990) 7-item commitment instrument, including, 'I enjoy discussing my organisation with people outside'. The Cronbach’s alpha for the affective commitment measure was 0.87 .

Our analysis also included control variables: age and gender. Following Metocchi (2002), these measures were included to reduce the chance that unmeasured variables could explain the results and to improve generalisability. Age and tenure were continuous variables. Gender was coded as a dichotomous variable (male $=1$; female $=0$ ).

\section{Quantitative Analysis}

Regression analyses and a MANOVA were undertaken to examine and compare the impact of supervisor/nurse relationships upon first, nurses' perceptions of empowerment, and second, affective commitment. Factor analysis was undertaken to ensure the integrity of the data.

\section{Qualitative data}

The qualitative data were collected through focus groups and interviews. Qualitative data about the factors affecting affective commitment were collected primarily from focus groups, each involving five nurses, plus some individual interviews. Participation was voluntary and the group sessions were commonly conducted during change-over periods between shifts, lasting 45 to 75 minutes. In some cases, to fit in with the busy nurse schedules, some individual nurses were interviewed. These interviews each lasted approximately 20 minutes. Focus groups and interviews were audio-taped. At total of 136 nurses (75 nurses in the public sector and 61 in the private sector) participated in the focus groups or interviews.

\section{Quantitative Analysis}

For the focus groups, demographic details were collected first, followed by discussions about factors influencing affective commitment in the hospital. The tape-recorded data were transcribed 
and categorised based on 'commonalities and differences' across emerging themes and then frequencies for each category were determined (Ghauri and Gronhaug 2002). The systematic patterns that emerged were used to draw conclusions to support (or not) the quantitative data.

\section{RESULTS}

\section{Quantitative Results}

\section{Sample}

To gather data from nurses, 5,245 anonymous surveys were distributed to 10 hospitals. The response was 1238 useable surveys, inferring a response rate of approximately $28.29 \%$. This marked a satisfactory response rated for social science research (Alreck and Settle, 1995).

Nurses were from public $(\mathrm{N}=383)$ and private $(\mathrm{N}=900)$, urban and regional, large (metropolitan), medium and smaller hospitals, located in four states of Australia (see Table 2). The majority of private sector (96.4\%) and public sector (87.3\%) nurses were female. The majority of private sector (54\%) and public sector (53.5\%) nurses were aged over 45 years, with a minority aged less than 30 years in the private sector (8.2\%) and the public sector $(20.11 \%)$. The remainder of the private sector (37.7\%) and the public sector (26.33\%) were aged between 30 and 45 years.

\section{Factor Analysis}

The correlation matrix identified many correlations exceeding .3, indicating the matrix was suitable for factoring. The Bartlett's test for Sphericity was significant (Chi-square value=20,975.199, $\mathrm{p}<.001$. df 325) and the Kaiser-Meyer-Olkin (KMO) measure of sampling adequacy was .965 - well above the .6 requirement. When Principal Axis Factoring was undertaken to extract the variables, three factors had Eigen values greater than one and $80.589 \%$ of the variance could be explained using these three factors.

\section{Correlation Matrix}

Table 2 details the correlation coefficients for each variable. All variables were significantly related to one another. The Cronbach's Alpha scores measuring reliability ranged from 0.86 to 0.93 . 
[Insert Table 2 here]

Hypothesis 1: To address the first hypothesis (Public and private sector nurses' satisfaction with their supervisor-subordinate relationships is positively associated with their perceptions of psychological empowerment) a regression analysis was undertaken and the findings suggest that the hypothesis is supported (see Table 3). The findings indicate that private sector nurses' satisfaction with their supervisor-nurse relationships accounted for $13.8 \%$ of their perceptions of empowerment. The mean for satisfaction with supervisor-nurse relationships $(m=4.70)$ suggests that nurses are more than satisfied. The mean for empowerment (4.11) suggests that nurses perceive themselves as empowered, hence the hypothesis is supported. Public sector nurses' satisfaction with their supervisor-nurse relationships accounted for $16.8 \%$ of their perceptions of empowerment. Moreover, the mean for satisfaction with supervisor-nurse relationships $(m=3.61)$ indicates these nurses report being neither dissatisfied nor satisfied. The mean for empowerment (3.94) suggests that they feel almost empowered. The findings support the trend that the higher the levels of satisfaction with supervisor-nurse relationship, the greater are nurses' perceptions of empowerment. Neither age nor gender was significant for public sector nurses, but age was significant for private sector nurses.

\section{[Insert Table 3 here]}

Hypothesis 2: To address the second hypothesis (Public and private sector nurses' perceptions of psychological empowerment are positively associated with their levels of affective commitment) a regression analysis was undertaken and the findings suggest that the hypothesis is supported (See Table 4). The findings indicate that private sector nurses' perceptions of empowerment accounts for $27 \%$ of their affective commitment. Additionally, the means for empowerment $(\mathrm{m}=4.11)$ and affective commitment (3.73) suggest these nurses perceive themselves to be empowered and slightly less than committed. Public sector nurses’ perceptions of empowerment account for 9.8\% of their affective commitment. The means for empowerment $(m=3.9)$ and affective commitment 
(2.98) suggest that these nurses perceive themselves as reasonably empowered, but uncommitted to their hospital. The findings suggest that the higher the perceptions of empowerment, the higher the levels of affective commitment.

\section{[Insert Table 4 here]}

Hypothesis 3: To address the third hypothesis (Public and private sector nurses' affective commitment is positively associated with their perceptions of psychological empowerment and supervisor-nurse relationships), an hierarchical regression analysis was undertaken and the findings suggest that the hypothesis is supported (See Table 5). The findings indicate that neither age nor gender was not significant for the private sector nurse sample, however gender was significant in the public sector sample. Additionally, private sector nurses' perceptions of empowerment and supervisor-nurse relationships account for $21.6 \%$ of the variance explaining their affective commitment. The mean for affective commitment was 3.73, meaning that, on average, most 'agree' that they are committed. Public sector nurses' perceptions of empowerment and supervisor-nurse relationships account for $28.2 \%$ of the variance explaining their perceptions of affective commitment. The mean for affective commitment was 2.98, indicating these nurses, on average, are not committed. These same variables account for varying degrees of affective commitment. One explanation is that management practices are indeed different across private and public sector hospitals.

\section{[Insert Table 5 here]}

Hypothesis 4: To address the fourth hypothesis (Private sector nurses experience higher levels of satisfaction with their supervisor-nurse relationships, and higher perceptions of psychological empowerment and affective commitment, compared with public sector nurses) a MANOVA was undertaken and the findings suggest that the hypothesis is supported. The findings indicate that there are significant differences in each of the levels of satisfaction of supervisor-nurse relationships, psychological empowerment and affective commitment between public and private sector nurses (see Table 6). 


\section{[Insert Table 6 here]}

\section{Qualitative Results}

\section{Sample}

The secondary data set comprised views from 75 public and 61 private sector nurses. The combined samples $(\mathrm{N}=136)$ comprised $87.6 \%$ female, with $28 \%$ aged over 45 years, 52\% aged 30-45 years and 20\% aged less than 30 years. For the private sector, the majority was female (85.5\%) and aged between 30 and 45 years (43.5\%), and similarly for the public sector, the majority was female (89.3\%) and aged between 30 and 45 years (60\%).

\section{Results from analysis}

Findings from analysis of the qualitative data support the quantitative results, suggesting that both public and private sector nurses' perceptions of affective commitment are strongly determined by their supervisor-nurse relationships. For nurses in both sectors, management practices and the actions of supervisors appeared to be critical to perceptions of their organisational commitment. The most frequent positive themes for both groups concerned workplace relationships and teamwork as being central to nurses' commitment. For the public sector, management support was reported as also important for commitment, but for the private sector, the actual nature of their work was the next most reported important factor affecting commitment. In contrast, negative themes for both groups were about perceptions of high workloads, inadequate resourcing and poor management (see Tables 7 and 8).

[Insert Tables 7 and 8 here]

\section{DISCUSSION}

This paper compared the responses of nurses working in public and private hospitals in Australia on nurses' satisfaction with their supervisor-nurse relationships, plus their perceptions of empowerment and affective commitment. Private sector nurses were substantially more satisfied 
with their subordinate-supervisor relationships as compared with their public sector counterparts. Satisfaction with supervisor-nurse relationships is important because past research has identified that these relationships affect the retention of nurses (Cohen, 2006) and those reporting dissatisfaction are more likely to leave (Gray and Phillips, 1994; Second and Smith, 1997).

The results suggest supervisor-nurse relationships predict over a tenth of private sector nurses’ perceptions of empowerment and nearly a fifth of public sector nurses' empowerment. Given the increasing evidence of the impact of empowerment to job satisfaction (Laschinger et al. 2004) and perceptions of quality of care (Leggat, Bartram, Casimir and Stanton, 2010), better understanding of the effect of supervisor-nurse relationships upon psychological empowerment is useful. In circumstances where increased workloads, inadequate wages, and low social status are common causes for nurses’ movement into other occupations (Yun, Jie, and Anli, 2010), our results suggest that hospitals have the opportunity to entice nurses to remain by increasing supervisors' abilities to improve current relationships with their nurses.

We next compared the impact of public and private sector nurses' perceptions of empowerment on affective commitment. The findings suggest that empowerment predicts over a quarter percent for private sector nurses' commitment to their hospitals and almost a tenth for public sector. This is consistent with previous findings (Gomez and Rosen, 2001) and is important because nurses' perceptions of empowerment significantly affect their loyalty and emotional attachment to their hospitals (Linden et al., 2000).

Third, we identified that supervisor-subordinate relationships and psychological empowerment account for a fifth of the variance of affective commitment of private sector nurses and over a quarter of the variance for public sector nurses. This is supported by previous research that also concludes that affective commitment is a strong predictor of turnover intentions (Meyer and Allen, 1997; Pitt, et al., 1995).

Our findings from the qualitative data strongly support the importance of supervisorsubordinate relationships and subsequent effects on psychological empowerment and affective 
commitment. Laschinger, Purdy and Almost (2007) found similar results in the relationship between front-line nurse managers and their immediate supervisors. In cases where nurse managers perceived a positive relationship with their immediate supervisor, those authors found they were more likely to report being empowered and satisfied with their jobs. Job satisfaction and empowerment were important predictors of intention to leave. Our findings suggest the same relationships exist for nurses within the Australian context, and that improving the relationships between nurses and their nurse unit managers is likely to have positive impacts on the retention of nurses in both public and private hospitals. A stronger effect is expected within the public sector due to higher levels of bureaucratisation and ongoing reforms.

Fourth, the findings suggest significant differences between the two samples. In particular, private sector nurses appear to be significantly more satisfied with their supervisor-subordinate relationships, perceive themselves as being slightly more empowered and substantially more committed to their hospitals, compared with public sector nurses. Hegney, Plank and Parker (2006) also found that nurses in private hospitals in Australia were more likely than nurses in public hospitals to perceive that autonomy was encouraged. In Australia, public hospitals have more difficulty recruiting and retaining nurses, and consequently rely more heavily on casual nurses than do private hospitals (Hegney, et al., 2003). This is important, as research has demonstrated that nurse perceptions of the highest quality of care are often provided by permanent rather than casual nurses (Lumley, Stanton and Bartram, 2004).

These findings raise some important issues for healthcare managers. It is costly to educate and train nurses, and poor management practices that lead to poor supervisor-subordinate relationships are problematic for all healthcare stakeholders, including patients, clinicians, hospital managers and taxpayers. Steane (1997) argued that major differences in the healthcare management found in private sector hospitals compared with public sector hospitals may be related to the differences in their managements' values. For example, public sector management reforms have focused strongly on cost-cutting and efficiency measures, resulting in increased workloads for 
nurses and supervisors have been expected to implement these changes. It is therefore perhaps not surprising that public sector nurses were less satisfied with supervisor-subordinate relationships when working within this context. One explanation for the significant differences in nurses' satisfaction with supervisor-subordinate relationships, psychological empowerment and affective commitment in this study may be related to the differences in such management values. However, such management strategies are not sustainable, especially considering the shortage of nurses and the cost involved in employing and training them.

Nurse unit managers are in a position to enhance psychological empowerment and affective commitment of nurses by utilising transformational leadership strategies to effectively communicate and implement key HRM strategies (e.g., extensive training, teamwork and decentralised decision making, greater information sharing and reasonable workloads). These practices would ensure that nurses are able to effectively practice the full scope of their professional activities (Ning, Zhong, Libo and Qiujie, 2009). Our findings suggest that there is much to be gained at the unit level by making sure that nurse managers have the knowledge, skills and abilities to translate HR policies and practices to empower and support their staff (Bartram, Stanton, Leggat, Casimir and Fraser, 2007; Leggat et al., 2010). This is further supported by Upenieks (2003), who argues that some of the success of magnet hospitals may be related to the model that encourages decision making decentralised to the unit level, using a shared governance model that offers nurses as much discretion as possible to use their expert skills in contributing to patient care.

\section{Limitations}

The main limitation in this research is the use of self-report surveys which can cause common method bias. However, Spector (1994) argues that the self-reporting method is legitimate for gathering data about employees' perceptions, providing that instruments used reflect an extensive literature review. Moreover, pattern-matching and triangulation of qualitative data should also be used to support interpretations of the data. This research paper has used all of 
these methods to improve the reliability and validity of our research findings. Another limitation is that there was a significant difference in the age of the two samples, with the public sector nurses being significantly younger. Further studies exploring the impact of age in these circumstances may be worthwhile, because past research has identified differences in workforce participation based on generational cohorts (Crumpacker and Crumpacker, 2007). This may affect the development of effective supervisor-subordinate relationships.

\section{CONCLUSION}

Nursing is facing shortages in many countries globally, and effective retention strategies are eagerly sought. This Australian study examined both private and public sector hospital nurses' supervisornurse relationships, the resultant perceptions of empowerment and thereby, nurses' commitment to their hospitals. The findings indicate that present management practices are not ideal for promoting the very workplace relationships needed to support effective healthcare and to increase retention. One lesson for healthcare management is to ensure high quality relationships between supervisors and their nurses at all levels. For all nurses, irrespective of hospital sector, not only will they be more productive when they experience high quality supervision, but this supportive environment also enhances their perceptions of empowerment and thereby, their commitment to their hospital. One important consequence of this is the likely increased retention of nurses.

The findings of the paper are important for healthcare researchers and managers (particularly public sector) because, as Ackroyd et al. $(2007,23)$ argued there has been little attempt by government to 'evaluate whether management reforms ... actually work' for all stakeholders concerned. While numerous factors will have affected the success of reforms, it could be argued that if the reforms had been successful, then there would be adequate nurses (and other healthcare professionals) in the public hospitals. Hence, this comparison of public and private sector nurses' attitudes towards some management practices sheds new light on what needs to change to keep nurses empowered in their jobs, and entice them to remain at their hospitals. 


\section{REFERENCES}

Allen, N.J. and Meyer, J.P. (1990), 'The measurement and antecedents of affective, continuance, and normative commitment to the organisation, Journal of Occupational and Organisational Psychology, 63: 1-8.

Alreck, P.L., and Settle, R.B. (1995), The Survey Research Handbook. Second Edition: Guidelines and Strategies for conducting a survey.

Australian Bureau of Statistics (ABS) (2005) Australian Social Trends: Australian Bureau of Statistics, Canberra.

Australian Bureau of Statistics (ABS) (2009) Australian Social Trends: Australian Bureau of Statistics, Canberra.

Australian Institute of Health and Welfare. (2008), Australian Hospital Statistics 2006-07. Canberra.

Aviolio, B. J., Zhu, W., Koh, W., and Bhatia, P. (2004), ‘Transformational leadership and organizational commitment: mediating role of psychological empowerment and moderating role of structural distance', Journal of Organizational Behavior, 25: 951-968.

Baldwin, N. (1990), 'Perceptions of pubic versus private sector personnel and informal red tape: their impact on motivation', American Review of Public Administration, 20: 7-27.

Bartram, T., Stanton, P., Leggat, S., Casimir, G., and Fraser, B. (2007), 'Lost In Translation:Exploring the Link between HRM and Performance in Health Care,' Human Resource Management Journal, 17: 21-41.

Basu, R. and Green, S.G. (1995), 'Subordinate Peformance, Leader-Subordinate Compatibility and Exchange Quality in Leader-Member Dyads: A field study', Journal of Applied Social Psychology, 25(1): 77-92.

Berta, W., LaPorte, A., and Valdemanis, V. (2005), 'Observations on institutional long-term care in Ontario: 1996-2002’, Canadian Journal of Aging, 24: 70-84.

Bolton, S.C. (2001), 'Changing faces: nurses as emotional jugglers', Sociology of Health and Illness, 23(1): 85-100.

Bolton, S.C. (2002), Consumer as King in the NHS. International Journal of Public Sector Management, 16(2): 122-130

Bolton, S.C. (2003), 'Multiple Roles? Nurses as Managers in the NHS', International Journal of Public Sector Management, 16(2): 122-130.

Bolton, S.C. (2004), 'A simple matter of control? NHS hospital nurses and new management', Journal of Management Studies, 41(2): 317-333. 
Boyle D.K., Bott, M.J., Hansen, H.E., Woods, C.Q., and Taunton, R.L. (1999), 'managers' leadership and critical care nurses’ intent to stay, American Journal of Critical Care 8.6, 361-71.

Boyne, G. A. (2002), 'Public and private management: what's the difference? Journal of Management Studies, 39(1): 97-122.

Buchanan, J. and Considine, G. (2002), Stop telling us to cope! NSW Nurses explain why they are leaving the profession. NSW Nurses Association, Australian Centre for Industrial Relations Research and Training: University of Sydney Press, Sydney.

Brunetto, Y, Farr-Wharton, R. and Shacklock, K. (2010), 'The impact of supervisor-subordinate relationships on morale: implications for public and private sector nurses' commitment', Human Resource Management Journal, 20(2): 206-225.

Buchan, J. and Calman L (2004), The Global Shortage of Registered Nurses: An Overview of Issues and Actions. International Council of Nurses, Geneva.

Buerhaus, P., Staiger, D.O. and Auerbach, D. (2007) 'Better late than never: workforce supply implications of later entry into nursing, Health Affairs, 26(1): 178-185.

Cohen, D. (2006), ‘The aging nursing workforce: How to retain experienced nurses’ Journal of Healthcare Management, 51(4): 233-245

Conger, J. A., and Kanungo, R. N. (1988), 'The empowerment process: integrating theory and practice', Academy of Management Review, 13(3): 471-482.

Coursey, D., and Bozeman, B. (1990), 'Decision making in public and private organisations: a test of alternative concepts of publicness', Public Administration Review, 50: 525-535.

Crumpacker, M and Crumpacker, J.M. (2007), Succession planning and generational stereotypes: Should HR consider age-based values and attitudes a relevant factor or passing fad?, Public Personnel Management, 36(4): 349-369.

DeCotiis, T. and Summers, T. (1987), 'A path-analysis of a model of the antecedents and consequences of organizational commitment', Human Relations, 40(7): 445-70.

Duckett, S. J., and Jackson, T. J. (2000), 'The new health insurance rebate: an inefficient way of assisting public hospitals', Medical Journal of Australia, 172: 439-442.

Dunham, R.B., Grube, J.A., and Castaneda, M. B (1994), 'Organizational commitment: The utility of an integrative definition’ Journal of Applied Psychology, 79(3): 370-380.

Eisenberger, R., S. Armeli, B. Rexwinkel, P. D. Lynch and L. Rhoades (2001), 'Reciprocation of Perceived Organizational Support’, Journal of Applied Psychology 86: 42-51.

Ghauri, P. and Gronhaug, K. (2002), 'Research methods in business studies: a practical guide’ Financial Times-Prentice-Hall, Harlow, United Kingdom. 
Graen, G.B and Uhl-Bien, M. (1995), Relationship-based approach to leadership: Development of leader-member exchange (LMX) theory of leadership over 25 years: Applying a multilevel multi, Leadership Quarterly 6(2): 219-247.

Gray, A.M. and Phillips, V.L. (1994), 'Turnover, age and length of service: a comparison of nurses and other staff in the National Health Service, Journal of Advanced Nursing, 19: 819-827.

Gregersen, H.B. and Black, J.S. (1992), 'Antecedents to commitment to a parent company and a foreign operation’, Academy of Managerial Journal, 35(1): 65-90.

Gollan, P. (2005), 'High Involvement management and human resource sustainability: The challenges and opportunities', Asia Pacific Journal of Human Resources, 43(1): 18-33.

Gomez C. and Rosen B. (2001), 'The leader-member exchange as a link between managerial tract and employee empowerment', Group Organisation management 26: 53-69.

Gerstner, C.R. and Day, D.V. (1997), 'Meta-analytic review of leader-member exchange theory: Correlates and construct issues’, Journal of Applied Psychology, 82(6): 827-844.

Hardie, E. A., and Critchley, C. R. (2008), 'Public perceptions of Australia's doctors, hospitals and health care systems', Medical Journal of Australia, 189(4): 210-214.

Harmon J, Scotti DJ, Behson B, Farias G, et al. (2003), 'Effects of high-involvement work systems on employee satisfaction and service costs in veterans' healthcare', Journal of Healthcare Management, 48( 6): 393-406.

Hegney D, Plank A and Parker V. (2003),' Nursing workloads: the results of a study of Queensland nurses', Journal of Nursing Management, 11: 307-14.

Hegney D, Plank A and Parker V. (2006), 'Extrinsic and intrinsic work values: their impact on job satisfaction in nursing', Journal of Nursing Management, 14: 271-81.

Herman, R.E. and Gioia, J.L. (1998), 'Making work meaningful: Secrets of the future-focused corporation', Futurist, 32(9): 24-38.

Kanter, R. M. (1993), Men and Women of the Corporation. New York: Basic Books.

Kirkman, B, I. and Rosen, B. (1999),' Beyond self-management: Antecedents and Consequences of team empowerment', Academy of Management Journal, 42(1): 58-74.

Kirkpatrick, I., Ackroyd, S. and Walker, R. (2004),The New Managerialism and Public Service Professions, London, Palgrave.

Larrabee, J. H., Withrow, M. L., Janney, M. A., Hobbs, G. R., Ostrow, C. L., and Burant, C. (2003), 'Predicting registered nurse job satisfaction and intent to leave', Journal of Nursing Administration, 33(5): 271-283.

Laschinger, H.K.S., Shamian, J. and Thomson, D. (2001), 'Impact of Magnet Hospital characteristics on Nurses' perceptions of trust, burnout, quality of care, and work satisfaction', Nursing Economics, 19(5): 209-219. 
Laschinger, H. K. S., Finegan, J., Shamian, J., and Wilk, P. (2004), 'A longitudinal analysis of the impact of workplace empowerment on work satisfaction', Journal of Organizational Behavior, 25(4): 527-you need a page number for this.

Laschinger HKS, Purdy N. and Almost J. (2007), 'The impact of leader-member exchange quality, empowerment and core self-evaluation on nurse manager's job satisfaction', The Journal of Nursing Administration, 37(5): 221-229.

Leggat, S.G., Bartram, T. Casimir, G. and Stanton, P. (2010), 'Nurse perceptions of the quality of patient care: confirming the importance of empowerment and job satisfaction', Health Care Management Review, 35(4): 1-10.

Linden, R.C., Wayne, S.J. and Sparrowe, R.T. (2000), 'An examination of the mediating role of psychological empowerment on the relations between the job, interpersonal relationships and work outcomes', Journal of Applied Psychology, 85(3): 407-416.

Lloyd, P., Braithwaite, J., and Southon, G. (1999), 'Empowerment and the performance of health services', Journal of Management in Medicine, 13(2): 83-94.

Lumley, C., Stanton, P. and Bartram, T. (2004), Casualisation friend or Foe? A case study investigation of two hospitals, New Zealand Journal of Employment Relations, 29(2): 3348.

Mathieu, J. E. and Zajac, D. M.(1990), A review and meta-analysis of the antecedents, correlates, and consequences of organizational commitment, Psychological Bulletin, 108,2, 171- 194

McGregor, M. J., Cohen, M., McGrail, K. M., et al., (2005), 'Staffing levels in not-for-profit and for profit long-term care facilities: Does type of ownership matter?' Canadian Medical Association Journal, 172: 645-9.

McGrail, K. M., McGregor, M. J., Cohen, M., Tate, R. B., and Ronald, L. A. (2007), 'For-profit versus not-for-profit delivery of long-term care’, Canadian Medical Association Journal, 176(1): 57-58.

Metocchi, M. (2002), 'The influence of leadership and member attitudes in understanding the nature of union participation', British Journal of Industrial Relations, 40: 87-111.

Meyer, J.P., Allen, N.J., and Gellatly, I. R. (1990), 'Affective and continuance commitment to the organization’, Human Resource Management Review, 1: 61-89.

Meyer, J. P. and Allen, N. J. (1997), Commitment in the Workplace, Theory, Research and Application, Thousand Oaks, London, New Delhi.

Morrison, R. S., Jones, L., and Fuller, B. (1997), 'The relation between leadership style and empowerment on job satisfaction of nurses', Journal of Nursing Administration, 27(5): 27-34. 
Moseley, A.L., Jeffers, L., and Paterson, J.B. (2008), 'The retention of the older nursing workforce: a literature review exploring factors which influence the retention and turnover of older nurses', Contemporary Nurse, 30(1): 46-56.

Mottaz, C.J., (1988), 'Determinants of organizational commitment', Human Relations, 41: 467-482.

Mrayyan, M.T. (2005) Nurse job satisfaction and retention: comparing public to private hospitals in Jordan. Journal of Nursing Management 13(1): 40-50.

Morris, J.H. and Sherman, J.D. (1981), 'Generalisability of an Organisational Commitmen model' Academy of Management Journal, Vol. 24(3): 512-526.

Mueller, B. H., \& Lee, J. (2002). Leader-member exchange and organizational communication satisfaction in multiple contexts. The Journal of Business Communication, 39: 220-244.

Ning, S., Zhang, H., Libo, W. and Qiujie, L. (2009), The impact of nurses empowerment on job satisfaction, Journal of Advanced Nursing, 65(12): 2642-2648.

Nunally, J. C. (1978). Psychometric Theory. New York: McGraw-Hill.

Pitt, M., Leyland, F., Foreman, S. K. and Bromfield, D. (1995). 'Organisational commitment and service delivery: Evidence from an industrial setting in the UK', International Journal of Human Resource Management, 6(1): 369-389.

Pollitt, C. (1995), 'Justification by works or by faith? Evaluating the new public management', Evaluation, 1(2): 133-154.

Rafferty, A.M., Clarke, S.P., Coles, J., Ball, J. and James, P. (2007), ‘Outcomes of variation in hospital nurse staffing in English hospitals: cross-sectional analysis of survey data and discharge records', International Journal of Nursing Studies, 44(2): 175-182.

Rainey, H. (1979), 'Perceptions of incentives in business and government: implications for Civil Service reform', Public Administration Review, 39: 440-448.

Robertson, I. K., and Richardson, J. R. J. (2000), 'Coronary angiography and coronary artery revascularisation rates in public and private hospitals after subacute myocardial infarction', Medical Journal of Australia, 173(6): 291-295.

Rhodes, S.R. and R.M. Steers. (1981). Conventional vs. worker-owned organizations, Human Relations, 24: 1013-1035.

Rousseau, D.M. (1989). 'Psychological and Implied Contracts in Organizations,' Employee Responsibilities and Rights Journal, 2: 121-139.

Schofield, D.J. and Beard, J.R. (2005), Baby boomer doctors and nurses: demographic change and transitions to retirement, Medical Journal of Australia, 183: 80-83.

Scotti, D. J., Harmon, J., and Behson, S. J. (2007), 'Links among high-performance work environment, service quality and customer satisfaction: an extension to the healthcare sector', Journal of Healthcare Management, 52(2): 109-125. 
Shacklock, K., Brunetto, Y. and Nelson, S. A. (2009), 'The different variables that affect older males 'and females' intentions to continue working', Asia Pacific Journal of Human Resources, 47(1): 79-101.

Sparrowe, R. and Linden, R. (1997), 'Process and Structure in Leader-Member Exchange’, Academy of Management Journal, 22(2): 522-552.

Spector, P. E. (1994), Using self-report questionnaires in OB research: A comment on the use of a controversial method, Journal of Organizational Behavior, 15: 385-392.

Spreitzer, G. (1995). Psychological empowerment in the workplace: dimensions, measurement and validation. Academy of Management Journal, 38: 1442-1465.

Spreitzer, G., Kizilos, M. A., and Nason, S. W. (1997), 'A dimensional analysis of the relationship between psychological empowerment and effectiveness, satisfaction, and strain', Journal of Management, 23(5): 679-704.

Steane, P. (1997), ‘Oils Ain’t Oils! Strategy Across Sectors’, International Journal of Public Sector Management, 10(6): 461-470.

Sutton Bell, N., and Narz, M. (2007), 'Meeting the challenges of age diversity in the workplace. The CPA Journal, 77(2): 56-59.

Taunton, R.L., Boyle, D.K., Woods, C.Q., Hansen, H.E. and Bott, M.J. (1997), 'Manager Leadership and Retention of Hospital staff nurses, Western Journal of Nursing Research, 19(2): 205-226.

Upenieks, V.V (2003), 'The interrelationship of organizational characteristics of magnet hospitals,nursing leadership and nursing job satisfaction', Healthcare Manager 22(2): 8398.

Walton, R.E. (1985). From control to commitment in the workplace, Harvard Business Review, 63(2): 77-84.

Wayne, S. J., Shore, L. M., and Liden, R. C. (1997), 'Perceived organizational support and leader member exchange A social exchange perspective', Academy of Management Journal, 40: 82-111.

Yrie, A. C., Hartman, S. J., and Galle, W. P. Jr. (2003), 'Examining communication style and leadermember exchange: Considerations and concerns for managers', International Journal of Management, 20: 92-100.

Yun, H., Jie, S. and Anli, J. (2010), Nursing shortage in China: State, causes and strategy, Nursing Outlook, 58: 122-128. 


\begin{tabular}{lllll}
\hline & $\begin{array}{l}\text { Urban/ } \\
\text { regional }\end{array}$ & $\begin{array}{l}\text { Dealing with } \\
\text { Acute cases }\end{array}$ & $\begin{array}{l}\text { Teaching } \\
\text { Hospital }\end{array}$ & $\begin{array}{l}\text { Large }>\mathbf{5 0 0} \text { beds, } \\
\text { Medium } \mathbf{3 0 0}-\mathbf{5 0 0} \text { beds, } \\
\text { Smaller }<\mathbf{3 0 0} \text { beds }\end{array}$ \\
\hline Private Hospital 1 & Urban & Yes & Yes & Large (578 beds) \\
Private Hospital 2 & Urban & Yes & No & Medium (416 beds) \\
Private Hospital 3 & Urban & Yes & No & Medium (317 beds) \\
Private Hospital 4 & Regional & Yes & No & Small (260 beds) \\
Private Hospital 5 & Urban & Yes & No & Small (239 beds) \\
Private Hospital 6 & Urban & Yes & No & Small (219 beds) \\
Private Hospital 7 & Regional & Yes & No & Small (206 beds) \\
Public Hospital 1 & Regional & Yes & Yes & Large (893 beds) \\
Public Hospital 2 & Urban & Yes & Yes & Large (760 beds) \\
Public Hospital 3 & Regional & Yes & No & Small (160 beds) \\
\hline
\end{tabular}

TABLE 2 Means, standard deviations, correlations and Cronbach's alpha coefficients

\begin{tabular}{|c|c|c|c|c|c|c|c|}
\hline Variable & Mean & $\begin{array}{l}\text { Standard } \\
\text { Deviation }\end{array}$ & 1 & 2 & 3 & 4 & 5 \\
\hline 1. Gender & & & 1 & & & & \\
\hline 2. Age & & & $126^{* *}$ & 1 & & & \\
\hline 3. LMX & 3.989 & 1.015 & $-.09 * *$ & $.08^{* *}$ & 1 & $(.80)$ & \\
\hline 4. Empowerment & 4.035 & .578 & -.046 & $.06 *$ & $.37 * *$ & 1 & $(.85)$ \\
\hline 5. Affective Commit & 3.379 & 1.012 & -.042 & $.07 * *$ & $.44^{* *}$ & $.41 * *$ & $1(.87)$ \\
\hline
\end{tabular}

${ }^{\mathrm{a}} \mathrm{N}=1283$. Numbers in parentheses on the diagonal are the Cronbach's alpha coefficients of the composite scales.

** Correlation is significant at the 0.01 level (2-tailed).

* Correlation is significant at the 0.05 level (2-tailed).

TABLE 3 Hierarchical Regression analyses detailing the relationships between supervisornurse relationships and perceptions of empowerment

\begin{tabular}{lcccc}
\hline $\begin{array}{l}\text { Psychological } \\
\text { empowerment }\end{array}$ & $\begin{array}{c}\text { Private sector } \\
\text { nurses } \\
\boldsymbol{\beta} \text { scores }\end{array}$ & $\begin{array}{c}\text { Private sector } \\
\text { nurses' } \\
\boldsymbol{\beta} \text { scores }\end{array}$ & $\begin{array}{c}\text { Public sector } \\
\text { nurses' } \\
\boldsymbol{\beta} \text { scores }\end{array}$ & $\begin{array}{c}\text { Public sector } \\
\text { nurses' } \\
\boldsymbol{\beta} \text { scores }\end{array}$ \\
\hline Age & $.19^{* *}$ & $.18^{* *}$ & -.04 & .009 \\
Gender & $.1^{* *}$ & .019 & -.004 & .047 \\
Supervisor- & $.318^{* *}$ & & $.413^{* *}$ \\
subordinate & & & \\
relationship & $17.118^{* *}$ & $47.618^{* *}$ & .522 & $31.022^{* *}$ \\
F & .037 & .138 & .002 & .168 \\
$\mathbf{R}^{2}$ & & &
\end{tabular}


TABLE 4 Hierarchical Regression analyses detailing the relationships between perceptions of empowerment and affective commitment

\begin{tabular}{lcccc}
\hline $\begin{array}{c}\text { Affective } \\
\text { commitment }\end{array}$ & $\begin{array}{c}\text { Private sector } \\
\text { nurses' } \\
\boldsymbol{\beta} \text { scores }\end{array}$ & $\begin{array}{c}\text { Private sector } \\
\text { nurses' } \\
\boldsymbol{\beta} \text { scores }\end{array}$ & $\begin{array}{c}\text { Public sector } \\
\text { nurses' } \\
\boldsymbol{\beta} \text { scores }\end{array}$ & $\begin{array}{c}\text { Public sector } \\
\text { nurses' } \\
\boldsymbol{\beta} \text { scores }\end{array}$ \\
\hline Age & .01 & .007 & .05 & .04 \\
Gender & -.05 & -.021 & $.23^{* *}$ & $.14^{* *}$ \\
Empowerment & 1.228 & $.47^{* *}$ & & $.219^{* *}$ \\
F & .01 & $110.119^{* *}$ & 26.978 & $37.879^{* *}$ \\
$\mathbf{R}^{2}$ & .27 & .057 & .098 \\
\hline$* *$ Correlation is significant at the 0.01 level (2-tailed). & &
\end{tabular}

Table 5 Hierarchical Regression analyses detailing the relationships between supervisornurse relationships with perceptions of empowerment and affective commitment

\begin{tabular}{lcccc}
\hline $\begin{array}{l}\text { Affective } \\
\text { commitment }\end{array}$ & $\begin{array}{c}\text { Private sector } \\
\text { nurses' } \\
\boldsymbol{\beta} \text { scores }\end{array}$ & $\begin{array}{c}\text { Private sector } \\
\text { nurses' } \\
\boldsymbol{\beta} \text { scores }\end{array}$ & $\begin{array}{c}\text { Public sector } \\
\text { nurses' } \\
\boldsymbol{\beta} \text { scores }\end{array}$ & $\begin{array}{c}\text { Public sector } \\
\text { nurses' } \\
\boldsymbol{\beta} \text { scores }\end{array}$ \\
\hline Age & .01 & .001 & $.23^{* *}$ & .03 \\
Gender & -.05 & -.02 & .05 & $.1^{* *}$ \\
$\begin{array}{l}\text { Supervisor- } \\
\text { subordinate }\end{array}$ & $.234^{* *}$ & & $.26^{* *}$ \\
relationship & & & & \\
Empowerment & & $.346^{* *}$ & & $.356^{* *}$ \\
F & 1.228 & $123.700^{* *}$ & $26.978^{* *}$ & $74.461^{* *}$ \\
$\mathbf{R}^{2}$ & .01 & .216 & .057 & .282 \\
\hline$* *$ Correlation is significant at the 0.01 level (2-tailed). & &
\end{tabular}

Table 6 Results of an MANOVA comparing the means for supervisor-nurse relationships, empowerment and affective commitment

\begin{tabular}{|c|c|c|c|c|c|}
\hline & \multicolumn{2}{|c|}{ Private sector $^{\#}$} & \multicolumn{2}{|c|}{ Public sector $^{\# \#}$} & \multirow[b]{2}{*}{ T value } \\
\hline & $\operatorname{Mean}^{\mathbf{a}}$ & SD & Mean & SD & \\
\hline LMX & 4.53 & .92 & 3.61 & .99 & $-12.54 * *$ \\
\hline Empowerment & 4.11 & 1.2 & 3.93 & 1.2 & $-4.59 * *$ \\
\hline Affective Commitment & 4.05 & 1.18 & 2.98 & 1.22 & $-14.16^{* *}$ \\
\hline
\end{tabular}

\footnotetext{
\# $\mathrm{N}=900 \quad{ }^{\# \#} \mathrm{~N}=383$

${ }^{\mathrm{a}}$ Mean: 1 = Strongly Disagree, through to 5 = Strongly Agree

** Correlation is significant at the 0.001 level (2-tailed).
}

TABLE 7 Public sector nurses: Factors affecting affective commitment $(\mathrm{N}=75)$ 


\begin{tabular}{|c|c|c|c|}
\hline Positive Themes & Frequency & Negative Themes & Frequency \\
\hline $\begin{array}{l}\text { Interpersonal relationships } \\
\text { with colleagues, supervisor and } \\
\text { clients }\end{array}$ & 19 (43.2\%) & $\begin{array}{l}\text { Workload } \\
\text { High patient/nurse ratio, } \\
\text { shortage of staff and high } \\
\text { workload }\end{array}$ & $18(58 \%)$ \\
\hline $\begin{array}{l}\text { Management } \\
\text { Flexible roster, good work } \\
\text { environment and support }\end{array}$ & $16(36.4 \%)$ & $\begin{array}{l}\text { Management } \\
\text { High level of unskilled staff, } \\
\text { Too much paperwork and lack } \\
\text { of support and poor } \\
\text { communication and training and } \\
\text { bad rosters }\end{array}$ & $9(29 \%)$ \\
\hline $\begin{array}{l}\text { Nature of work } \\
\text { Meaning of work and a sense of } \\
\text { autonomy in the workplace }\end{array}$ & 9 (20.4\%) & $\begin{array}{l}\text { Pay } \\
\text { Poor wages (compares to public } \\
\text { hospitals) and poor rewards (for } \\
\text { extra responsibilities) }\end{array}$ & $4(13 \%)$ \\
\hline Total & 44 & Total & 31 \\
\hline
\end{tabular}

TABLE 8 Private sector nurses: Factors affecting affective commitment ( $\mathrm{N}=61$ )

\begin{tabular}{|c|c|c|c|}
\hline Positive Themes & Frequency & Negative Themes & Frequency \\
\hline $\begin{array}{l}\text { Interpersonal relationships } \\
\text { Peer and NUM support, good } \\
\text { team relationships }\end{array}$ & $12(42.86 \%)$ & $\begin{array}{l}\text { Workload } \\
\text { Perception of overwork and } \\
\text { stress from understaffing, } \\
\text { high patient/nurse ratios and } \\
\text { high acuity }\end{array}$ & $13(39.4 \%)$ \\
\hline $\begin{array}{l}\text { Nature of work } \\
\text { Love my work - love nursing } \\
\text { here }\end{array}$ & $8(28.58 \%)$ & $\begin{array}{l}\text { Management } \\
\text { Autocratic mgt practices, } \\
\text { nepotism, lack of } \\
\text { consultation, }\end{array}$ & $12(36.37 \%)$ \\
\hline $\begin{array}{l}\text { Management } \\
\text { Flexible work options, mainly } \\
\text { from part time nursing staff }\end{array}$ & $5(17.86 \%)$ & $\begin{array}{l}\text { Lack of flexibility in work } \\
\text { options }\end{array}$ & $6(18.18 \%)$ \\
\hline Good training opportunities & $3(10.71 \%)$ & $\begin{array}{l}\text { Lack of good } \\
\text { communication processes is } \\
\text { frustrating }\end{array}$ & $2(6.06 \%)$ \\
\hline Total & 28 & Total & 33 \\
\hline
\end{tabular}

